\title{
Prognosis in IDH-Mutant and IDH-wild type glioblastoma
}

\section{IDH- Mutant ve IDH- Wild tip glioblastomda prognoz}

\author{
Eren Kılıç ${ }^{1}$, Neşe Yeldir², Ünal Özüm ${ }^{3}$ Birsen Yücel ${ }^{4}$, Mukaddes Yılmaz ${ }^{4}$, Hatice Özer ${ }^{2}$, H.Reyhan \\ E ğillmez ${ }^{2}$
}

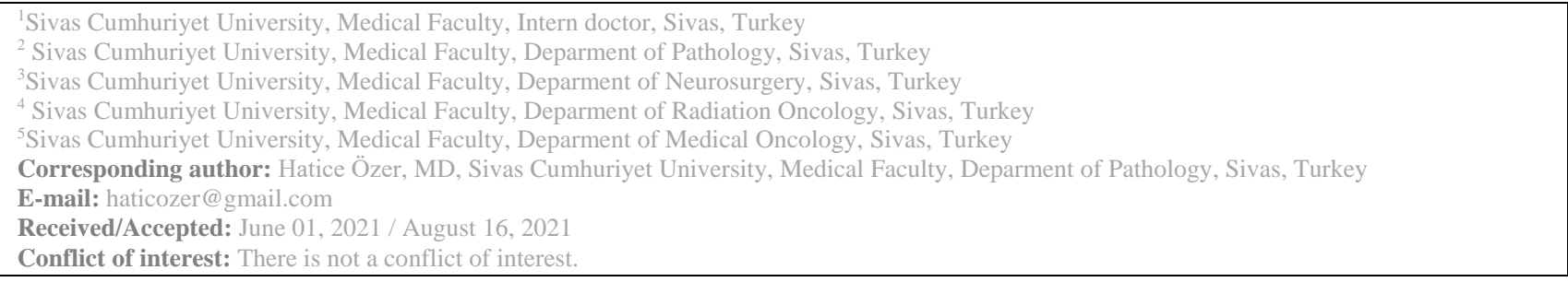

\begin{abstract}
SUMMARY
Glioblastoma (GBM) is the most common brain tumor in adults with a poor prognosis and predominantly astrocytic differentiation. GBM is classified according to the isocitrate dehydrogenase (IDH) mutation according to the World Health Organization (WHO) Brain Tumors 2016 classification. IDH1 gene mutations are evaluated immunohistochemically (IHC) and molecular methods in current pathology laboratory practice.

The aim of this study was to determine the overall survival in GBM cases according to IDH-1 mutation status and Ki-67 proliferation index.

Total of 53 patients diagnosed as GBM between 2007-2020 in Sivas Cumhuriyet University Faculty of Medicine, Department of Pathology were evaluated. Disease-free median survival of 7 (13\%) GBM patients with IDH mutation was 2 months (2-year survival 14\%), disease-free median survival 9 months (2-year survival $24 \%$ ) in GBM IDH-wild type cases. In cases with a higher Ki-67 proliferation index, the median disease-free survival were shorter.

In conclusion statistically significant results could not be obtained between disease-free survival in GBM IDH-mutant type and GBM IDH-wild type. However, the mean Ki-67 proliferation index of GBM IDH-wild type cases was found to be much higher than GBM IDH-mutant cases. High Ki-67 proliferation index was found to be associated with a significantly shorter survival.
\end{abstract}

(iD) Eren K1lıç

(D) Neşe Yeldir

(D) Ünal Özüm

(iD) Birsen Yücel

(D) Mukaddes Yilmaz

(D) Hatice Özer

(ID) H.Reyhan Eğilmez

ORCID IDs of the authors: E.K. 0000-0002-3396-5891 N.Y. 0000-0002-3812-6245 Ü.Ö. 0000-0003-2065-2033 B.Y. 0000-0002-0083-6866 M.Y. 0000-0002-7927-8480 H.Ö. 0000-0001-6479-3626 H.R.E. 0000-0001-9666-0246

Keywords: Glioblastoma, IDH-mutant type, IDH-wild type, Ki-67 proliferation index.

Glioblastom (GBM) kötü prognoza sahip, baskın olarak astrositik diferansiyasyon gösteren, erişkinlerde en sık görülen beyin tümörüdür. GBM, Dünya Sağlık Örgütü (DSÖ) Beyin Tümörleri 2016 sınıflamasına göre izositratdehidrogenaz (IDH) mutasyonuna göre sınıflandırılmıştır. Güncel patoloji laboratuvarı uygulamasında IDH gen mutasyonu immünohistokimyasal (IHK) ve moleküler olarak değerlendirilir.

Bu çalışmanın amacı, GBM olgularında IDH-1 mutasyon durumu ve Ki-67 proliferasyon indeksine göre genel sağ kalımın belirlenmesidir.

Sivas Cumhuriyet Üniversitesi Tıp Fakültesi Patoloji Anabilim Dalı’nda 2007-2020 tarihleri arasında GBM tanısı alan 53 olgu değerlendirildi. IDH mutasyonu olan 7 (\% 13) GBM hastasının hastalıksız median sağ kalım süresi 2 ay (2 yıllık sağ kalımları \% 14), IDH-wild tip 46 (\% 87) GBM olgusunda hastalıksız median sağ kalım süresi 9 ay (2 yıllık sağ kalımları \% 24) idi. Ki-67 indeks değeri yüksek olan olgularda hastalıksız median sağ kalım süresi daha kısa idi. 
Sonuç olarak IDH-wild tip ve IDH-mutant tip GBM olgularında hastalıksız sağ kalım süreleri arasında istatistiksel olarak anlamlı sonuçlar elde edilemedi. Ancak IDH-wild tip olguların ortalama Ki-67 proliferasyon indeksi IDH-mutant olgulara göre çok daha yüksek bulundu. Ki-67 proliferasyon indeksi yüksekliğinin ise anlamlı derecede daha kısa yaşam süresi ile ilişkili olduğu tespit edildi.

Anahtar sözcükler: Glioblastom, IDH-mutant tip, IDH-wild tip, Ki-67 proliferasyon indeksi.

\section{INTRODUCTION}

GBM is the most frequent malignant primary brain tumour in adults. Approximately $45-50 \%$ of primary malignant brain tumours. WHO Classification of Tumors of the Central Nervous System in which lacks mutations in the IDH1 and IDH2 genes as IHC and molecular methods. GBMs that do not show mutations are classified as IDHwild type. Mutating GBMs are classified as IDHmutant type. In cases where mutation can not be demonstrated or applied, GBM is classified as NOS $1-5$.

IDH1 and IDH2 mutations are positive prognostic factors, even after subtotal resection of tumours. The main treatment is total surgical resection followed by radiation therapy and/or synchronic chemotherapy (Temozolomide), then the adjuvant chemotherapy. Lack of IDH mutations in GBM, MGMT promoter methylation is a strong predictive marker for the efficiency of the chemotherapy agent ${ }^{1,6-11}$.

This study was planned retrospectively to determine the overall survival in GBM cases according to IDH-1 mutation status and $\mathrm{Ki}-67$ proliferation index.

\section{MATERIAL AND METHODS}

Cases diagnosed as GBM between 2007-2020 in Sivas Cumhuriyet University Faculty of Medicine, Department of Pathology were evaluated. Antibodies R132H-IDH1, ATRX, p53 and Ki-67 in IHC methods were applied to the cases diagnosed before 2016 using the Ventana Brand Benchmark $\mathrm{XT}$ model automatic device. Chi-square test was performed with descriptive statistical methods, using information about the patients' age, gender, comorbid diseases, tumoral multifocality, treatment, histopathological diagnosis and IHC staining results. In addition, the correlation between Ki-67 proliferation index and disease-free overall survival according to IDH mutation status was evaluated.
SPSS version 22 was used for statistical analysis. Descriptive tests (frequencies, descriptive, standard deviation) were used to describe the characteristics of the patients. Frequencies were compared with the Chi-Square test for categorical variables. The Student t-test was used to compare continuous variables. The Mann-Whitney $U$ test was used for groups which were not normally distributed. Kaplan Meier test was used for survival analysis. P-values $\mathrm{p}<0.050$ were considered as significant.

\section{RESULTS}

Histological examination, hypercellular tumor and pseudopalisading necrosis with or without vascular endotelial proliferation was diagnosed as GBM (Figure 1). The gender distribution of a total of 53 patients with GBM was 35 men $(66 \%)$ and 18 women (34\%). The age range was 36-79 (mean age: 58.5). Comorbid diseases (Diabetes, hypertension etc.) were found in 12 patients (23 $\%)$. Surgical procedures and post-surgical treatments applied to the patients are as follows: biopsy in 6 patients $(11 \%)$, subtotal resection in 36 patients $(68 \%)$, total resection in 11 patients $(21$ $\%)$ and radiotherapy in 3 patients (6\%), chemoradiotherapy in 50 patients $(94 \%)$, adjuvant chemotherapy in 31 patients (59\%).

Disease free median survival of 7 (13\%) GBM patients with IDH mutation was 2 months (2-year survival $14 \%$ ), disease free median survival 9 months (2-year survival $24 \%$ ) in IDH-wild type of 46 (87 \%) GBM cases (Figure 2). Ki-67 proliferation index ranged from $4 \%$ to $90 \%$, with a median value of $40 \%$. In cases with $\mathrm{Ki}-67$ proliferation index above $40 \%$, the median disease-free survival were 4 months and 2-year survival was $11 \%$; in patients with Ki-67 proliferation index below $40 \%$, the median survival time without disease is 13 months and the 2 -year survival is $28 \%$ (Figure 3 ). While the mean Ki -67 proliferation index was $36 \%$ for GBM IDHmutant type and $87 \%$ for GBM IDH-wild type (Table). 
Table: Survival according to Ki-67 proliferation index (Median value: 40\%)

\begin{tabular}{|c|c|c|c|}
\hline Ki-67 proliferation index & Median survival & 2-year survival & 5-year survival \\
\hline$\leq 40 \%(\mathrm{n}=30)$ & 13 months & $28 \%$ & $5 \%$ \\
\hline$>40 \%(\mathrm{n}=22)$ & 4 months & $11 \%$ & - \\
\hline
\end{tabular}

$\mathrm{p}=0.139$
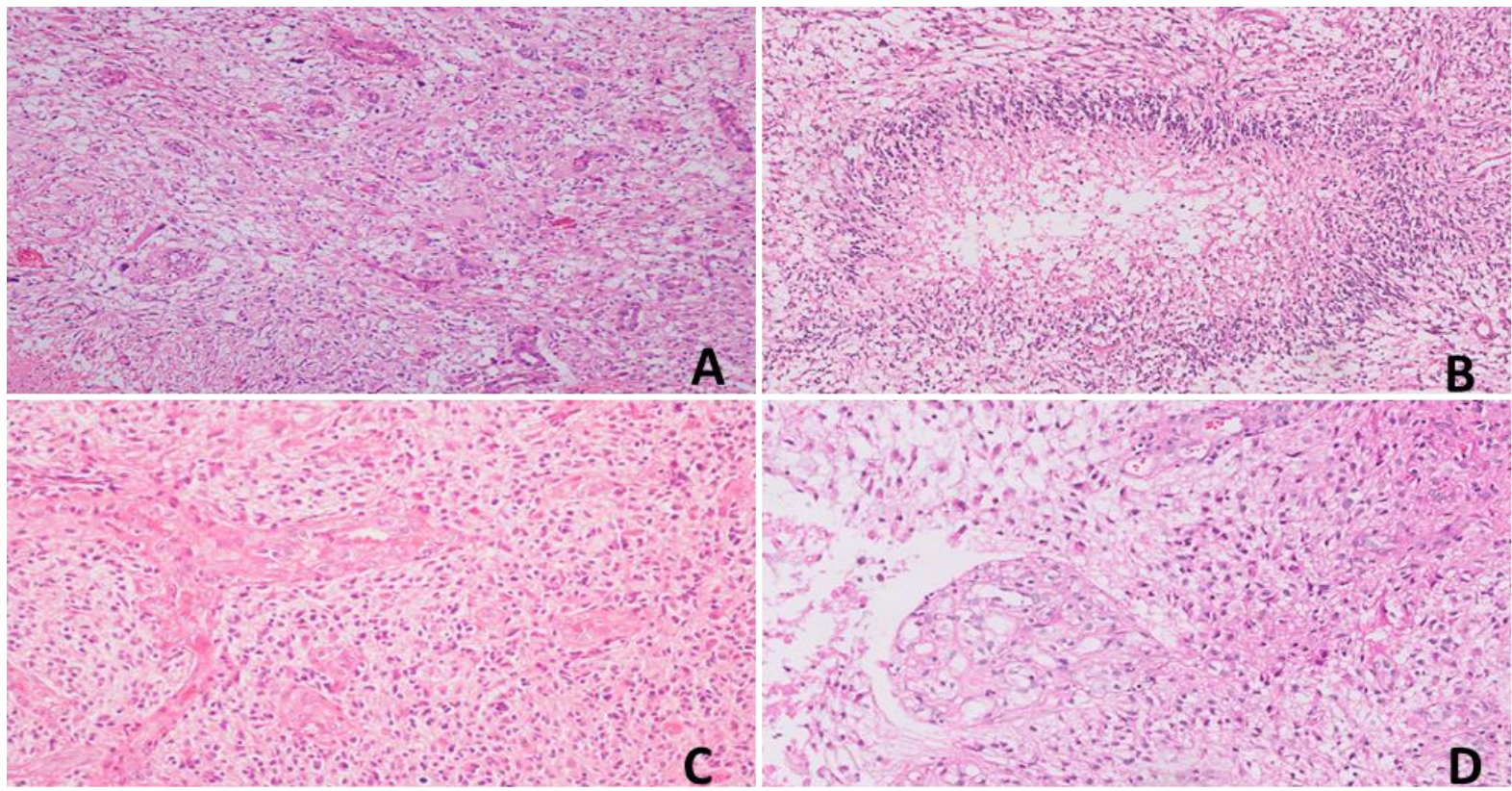

Figure 1: (A) Hypercellular areas and (B) pseudopalisading necrosis (H\&E; X40); (C) vascular endothelial proliferation and (D) glomeruloid vascular proliferation (H\&E; X100) in GBM

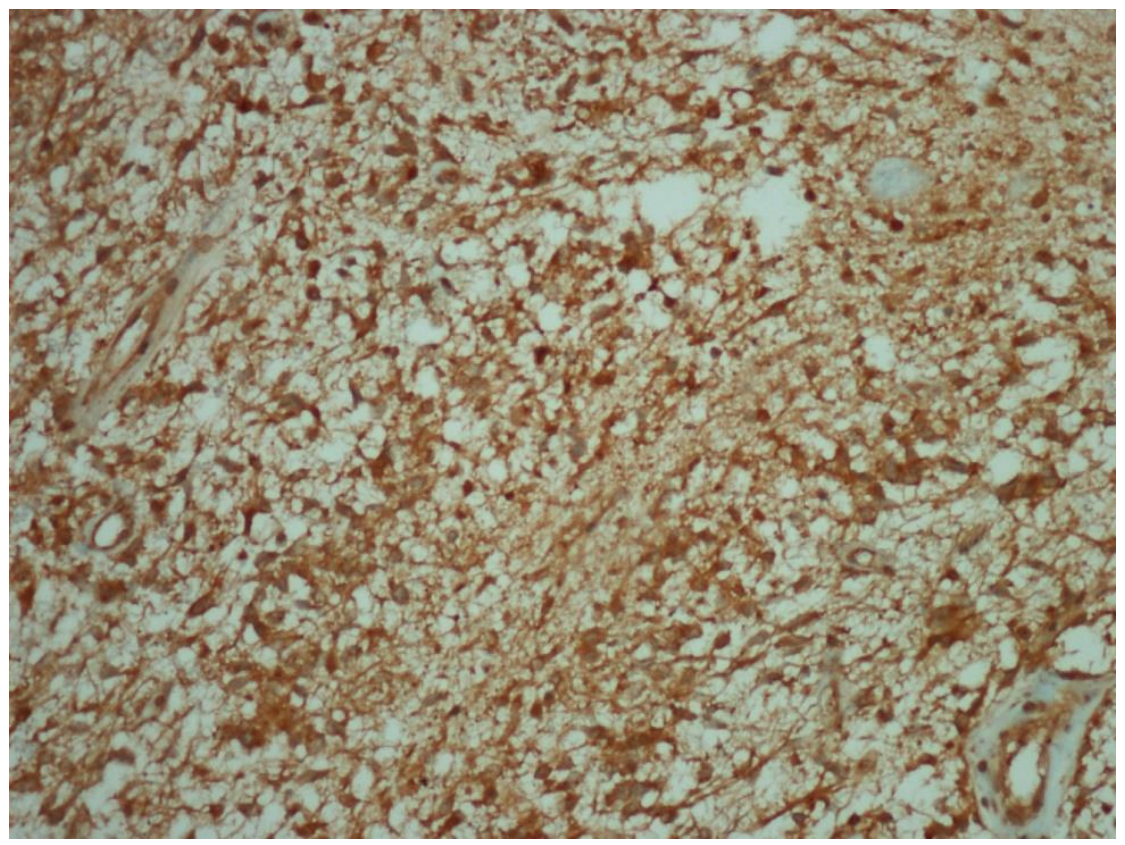

Figure 2: R132H-IDH1 is positive in tumor cells with a GBM IDH-mutant case (IHC; X100). 

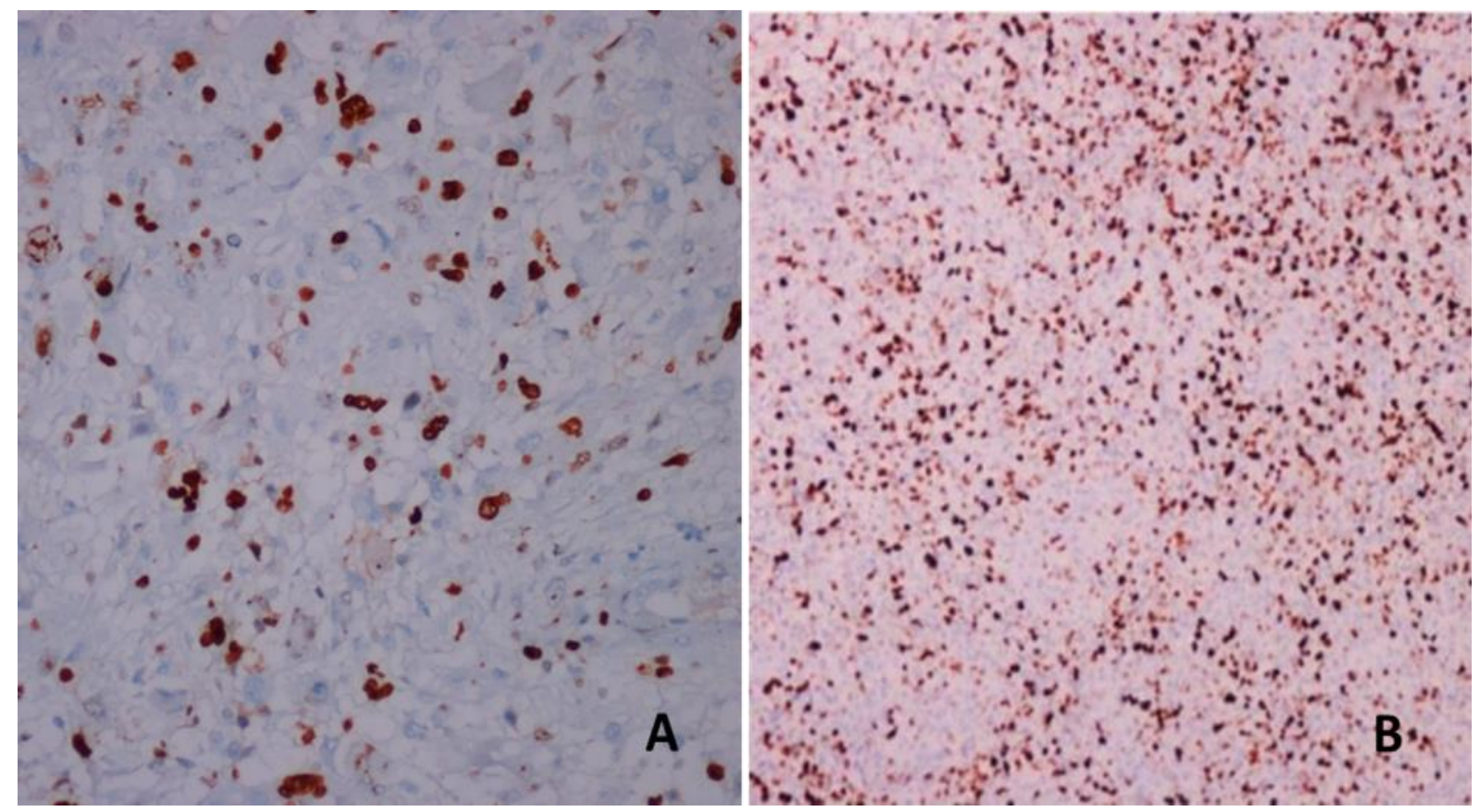

Figure 3: Shown by Ki-67 proliferation index $<40 \%$ (A) and $>40 \%$ (B) in GBM (IHC; X100 and IHC; $\mathrm{X} 40$ )

In one IDH-mutant case was ATRX loss. In the others, ATRX was retained. Additionally, p53 expression percentages were between $1(\%)$ and $95(\%)$ in all cases. The mean p53 expression value, was $36 \%$ for IDH-wild type cases and $34 \%$ for IDH-mutant type cases.

Non-interventional clinical trials were approved by the Ethics Committee of Sivas Cumhuriyet University, with the decision No: 2019-10/25.

\section{DISCUSSION}

GBM is the most common adult brain tumor with a poor prognosis and predominantly astrocytic differentiation ${ }^{1-7}$. Despite the great knowledge accumulated over many years about this tumor, curative treatment is still not possible. It constitutes $45-50 \%$ of all malignant brain tumors. Epidemiologically, the incidence is 3-4/100.000 in North America and Europe, while it is $0.59 / 100.000$ in Southeast Asia. It is most common between the ages of 55-85 (1, 2, 6-9). Mean age was 58.5 in our study.

Clinical findings are headache, focal seizures, focal deficits (muscle weakness, loss of sensation, aphasia, visual impairment, cognitive dysfunction) and increased intracranial pressure. GBM is classified according to the WHO Brain Tumors 2016 classification according to the IDH mutation. IDH1 and IDH2 gene mutations are evaluated IHC and molecularly, and GBMs that do not show mutations are classified as IDH-wild type. Mutating GBMs are classified as IDH-mutants.
Our cases contain 46 (87\%) GBM IDH-wild type and 7 (13\%) GBM IDH-mutant type.

Total excision of the tumor is important among the factors determining GBM prognosis. In our cases, subtotal resection was performed in 36 patients $(68 \%)$, and total resection was performed in 11 patients $(21 \%)$. Subtotally resected tumors are reported to be better prognostic factors in patients with IDH1 and IDH2 gene mutations ${ }^{2,7-11}$.

IDH mutation identification is important for diagnosis, prognosis and treatment. The most commonly used method for IDH mutation is IHC method. It is recommended to perform IDH sequencing in patients under 55 years of age in IDH-wild type GBMs that do not show mutations as IHC. The prognosis is 14 months in GBM-IDHwild type cases and 27 months in GBM IDHmutant type cases ${ }^{1,7-9}$.

Standard treatment is maximal surgical resection followed by radiotherapy and chemotherapy (Temozolamide), adjuvant chemotherapy containing Temozolamide ${ }^{1,7-9}$. In our cases, radiotherapy was applied to 3 patients (6\%), chemoradiotherapy was applied to 50 patients (94\%), and adjuvant chemotherapy was applied to 31 patients $(59 \%)$.

In our study, statistically significant results could not be obtained between disease-free survival times in GBM cases with and without IDH mutation. It is known in the literature that IDH-wild type GBM cases have shorter survival time. Because we have 
small number of IDH-mutant cases, our statistical results for survival time and IDH mutation situation are not significant. However, the mean Ki -67 proliferation index of IDH-wild type cases was found to be much higher than IDH-mutant cases. Higher Ki-67 proliferation index was found to be associated with a significantly shorter survival.

In conclusion, it is known from the current literature that GBM IDH-wild type cases have a more aggressive course and have a shorter mean survival time than GBM IDH-mutant type cases. The Ki-67 proliferation index, which is closely related to the proliferation capacity in malignant tumors, is also a prognostic factor that may be determinative for the mean survival for low grade and high grade astrocytic tumors.

Presented as a poster presentation at 30 th National Pathology Congresses.

Project T -902 was supported of Sivas Cumhuriyet University Scientific Research Board.

\section{REFERENCES}

1. Louis DN, Ohgaki H, Wiestler OD, Cavenee WK (Eds). WHO Classification of Tumours of the Central Nervous System. 4th ed, IARC, Lyon 2016. WHO

2. Ostrom QT, Gittleman H, Truitt G, et al. CBTRUS Statistical Report: Primary Brain and Other Central Nervous System Tumors Diagnosed in the United States in 2011-2015. Neuro Oncol 2018; 20 Suppl

3. Chang SM, Parney IF, Huang W, et al. Patterns of care for adults with newly diagnosed malignant glioma. JAMA 2005; 293: 557.
4. Yan H, Parsons DW, Jin G, et al. IDH1 and IDH2 mutations in gliomas. N Eng $1 \mathrm{~J}$ Med 2009; 360: 765 .

5. Gokden M. If it is not Glioblastoma then What is it? A Differential Diagnostic Review. Adv Anat Pathol. 2017 Nov; 24 (6): 379-391. doi: 10.1097/PAP.0000000000000170.

6. Eckel-Passow JE, Lachance DH, Molinaro AM, et al. Glioma Groups Basedon 1p/19q, IDH, and TERT Promoter Mutations in Tumors. N Engl J Med 2015; 372: 2499.

7. Reuss DE, Sahm F, Schrimpf D, et al. ATRX and IDH1-R132H immunohistochemistry with subsequent copy number analysis and IDH sequencingas a basis foran "integrated" diagnostic approach for adult astrocytoma, oligodendroglioma an dglioblastoma. ActaNeuropathol 2015; 129: 133.

8. Gramatzki D, Dehler S, Rushing EJ, et all. Glioblastoma in the Canton of Zurich, Switzerland revisited: 2005 to2009. Cancer. 2016 Jul 15; 122 (14): 2206-2215. doi: 10.1002/cncr.30023. Epub2016 Apr18.

9. Wirsching HG, Galanis E,Weeler $M$. Glioblastoma. Handb Clin Neurol 2016; 134: 381397. doi: 10.1016/B978-0-12-802997-8.00023-2

10. Wen PY, Weller M, Lee EQ, Alexander BM, et all. Glioblastoma in adults:a society for neuroOncology (SNO) and European Society of Neuro-Oncology (EANO) consensus review on current management anffd future directions. Neuro Oncol. 2020 Aug 17; 22 (8): 1073-1113. doi: 10.1093/neuonc/noaa106. PMID: 32328653.

11. Muir M, Gopakumar S, Traylor J, Lee S, Rao G. Glioblastoma multiforme: novel therapeutic targets. Expert Opin Ther Targets. $2020 \mathrm{Jul} ; 24$ (7): 605-614. doi: 10.1080/14728222.2020.1762568. 